\title{
Quantitative proteomics reveals new insights into calcium-mediated resistance mechanisms in Aspergillus flavus against the antifungal protein PgAFP in cheese
}

\author{
Josué Delgado ${ }^{a}$, Rebecca A. Owens ${ }^{b}$, Sean Doyle ${ }^{b}$, Félix Núñez ${ }^{a}$, Miguel A. Asensio ${ }^{a}{ }^{*}$ \\ ${ }^{a}$ Food Hygiene and Safety, Institute of Meat Products, University of Extremadura, Cáceres, Spain \\ ${ }^{\mathrm{b}}$ Department of Biology, Maynooth University, Maynooth, Co. Kildare, Ireland
}

\section{A R T I C L E I N F O}

\section{Article history:}

Received 23 December 2015

Received in revised form

24 February 2017

Accepted 21 March 2017

Available online 22 March 2017

\section{Keywords:}

Antifungal protein

Cheese

Proteomics

Calcium

Calcineurin

\begin{abstract}
A B S T R A C T
The ability of Aspergillus flavus to produce aflatoxins in dairy products presents a potential hazard. The antifungal protein PgAFP from Penicillium chrysogenum inhibits various foodborne toxigenic fungi, including Aspergillus flavus. However, PgAFP did not inhibit A. flavus growth in cheese, which was related to the associated cation content. $\mathrm{CaCl}_{2}$ increased $A$. flavus permeability and prevented PgAFP-mediated inhibition in potato dextrose broth (PDB). PgAFP did not elicit any additional increase in permeability of $\mathrm{CaCl}_{2}$-incubated $A$. flavus. Furthermore, PgAFP did not alter metabolic capability, chitin deposition, or hyphal viability of $A$. flavus grown with $\mathrm{CaCl}_{2}$. Comparative proteomic analysis after PgAFP treatment of A. flavus in calcium-enriched PDB revealed increased abundance of 125 proteins, including oxidative stress-related proteins, as determined by label-free mass spectrometry (MS)-based proteomics. Seventy proteins were found at lower abundance, with most involved in metabolic pathways and biosynthesis of secondary metabolites. These changes do not support the blockage of potential PgAFP receptors in A. flavus by calcium as the main cause of the protective role. A. flavus resistance appears to be mediated by calcineurin, G-protein, and $\gamma$-glutamyltranspeptidase that combat oxidative stress and impede apoptosis. These findings could serve to design strategies to improve PgAFP activity against aflatoxigenic moulds in dairy products.
\end{abstract}

(C) 2017 Elsevier Ltd. All rights reserved.

\section{Introduction}

Some moulds are able to produce mycotoxins in foods, which causes serious problems throughout the world. Aspergillus flavus is one of the most serious mould contaminants, due essentially to aflatoxin production in cereals and nuts. Additionally, A. flavus is able to grow and produce aflatoxins and cyclopiazonic acid on intermediate moisture foods, including ripened cheese (Kokkonen et al., 2005; Lie and Marth, 1967; López-Díaz et al., 1996). The strategies to prevent mycotoxin accumulation on ripened foods include taking advantage of antifungal proteins produced by moulds that prevent growth of mycotoxigenic fungi.

The antifungal protein PgAFP is produced by Penicillium chrysogenum CECT 20922 (formerly RP42C), that was isolated from drycured ham (Rodríguez-Martín et al., 2010). PgAFP belongs to a

\footnotetext{
* Corresponding author.

E-mail address: masensio@unex.es (M.A. Asensio).
}

group of small, basic, cysteine-rich proteins, which also includes PAF from P. chrysogenum (Marx et al., 1995), AFP from Aspergillus giganteus (Nakaya et al., 1990), and NFAP from Neosartorya fischeri (Kovács et al., 2011). PgAFP can efficiently inhibit various toxigenic moulds in culture medium, even A. flavus on a ripened meat product, but not Penicillium polonicum (Delgado et al., 2015a). A. flavus inhibition co-incides with increased permeability to SYTOX Green, depressed metabolic capability, compromised cell membrane, apoptosis, and necrosis. The proposed mechanism of action for PgAFP is based on the lower relative abundance of Rho GTPase Rho1 and G protein subunit $\beta$ CpcB leading to alteration of both cell wall integrity and response to oxidative stress (Delgado et al., 2015b). Conversely, higher levels of Rho GTPase Rho1 are involved in the resistance of $P$. polonicum leading to increased chitin biosynthesis (Delgado et al., 2016).

The presence of cations in the media has been shown to decrease the antifungal capability of these proteins (Galgóczy et al., 2013; Kaiserer et al., 2003; Theis et al., 2003; Thevissen et al., 1999, 1996). High levels of extracellular divalent or monovalent cations 
seem to reduce the ability of the antifungal protein to provoke permeabilization or altered calcium influx, as has been described for PAF (Binder et al., 2010), AFP (Theis et al., 2003), and NFAP (Galgóczy et al., 2013). However, the ultimate mechanism responsible for this effect has not been elucidated. High external calcium levels transiently increase cytosolic calcium levels in Aspergillus nidulans (Nelson et al., 2004). Intracellular $\mathrm{Ca}^{2+}$ is a secondary messenger regulating various responses to stress signals in fungi, including antifungal proteins (Binder et al., 2011, 2010). Given that divalent cations are present in several foods, particularly calcium in cheeses, the effect of high levels of this cation on PgAFP antifungal activity against sensitive moulds requires urgent evaluation.

Comparative proteomic analysis has been described as a powerful tool to study the unknown effect of substances on moulds and yeasts. It has been used to study the effect of $\mathrm{H}_{2} \mathrm{O}_{2}$ on moulds (Lessing et al., 2007) and to identify the mechanism of action of antifungal compounds (Cagas et al., 2011; Delgado et al., 2015b; Gautam et al., 2008). Comparative 2D-PAGE is able to distinguish changes in protein abundance, isoforms or post-translational modifications (Görg et al., 2004). However, this technique does not reveal the whole proteome, as it depends on the range of $\mathrm{pH}$ chosen (Görg et al., 2009), and it is not able to effectively analyse membrane and hydrophobic proteins (Rabilloud et al., 2009; Zhu et al., 2010). Label-free mass spectrometry-based proteomic analysis is able to identify proteins typically underrepresented in 2DPAGE studies (Owens et al., 2014), providing deeper proteome coverage. Thus, these two techniques can provide complementary information to study the PgAFP mechanism of action in moulds.

Results obtained from proteomic analysis guides the use of specific assays to elucidate the mechanisms of action. The relative abundance of $A$. flavus proteins can also give information about the differential response of this mould against PgAFP when grown in a calcium-enriched medium.

The objective of the present work was to evaluate the inhibitory activity of PgAFP against A. flavus growth in cheese, and to explore the effect of cations, mainly calcium, on PgAFP antifungal potential. The changes induced by high calcium levels, in the proteome profile and in selected metabolic and structural characteristics of $A$. flavus, with and without PgAFP, were assessed.

\section{Materials and methods}

\subsection{Strains}

The PgAFP producer Penicillium chrysogenum RP42C (Spanish Type Culture Collection, CECT 20922) and Aspergillus flavus CECT 2687 were used in this study. The latter produces aflatoxin in intermediate moisture foods (Bernáldez et al., 2014).

\subsection{PgAFP purification}

P. chrysogenum CECT 20922 was grown in potato dextrose broth (PDB, Scharlab, Barcelona, Spain) $\mathrm{pH} 4.5$, at $25{ }^{\circ} \mathrm{C}$ for 21 days without shaking. Mycelia were removed, the culture medium was filtered to obtain cell-free medium and PgAFP was obtained by Fast Protein Liquid Chromatography as previously described (Acosta et al., 2009; Rodríguez-Martín et al., 2010). Briefly, the cell-free medium was separated by chromatography on cationic and gel filtration columns, the sub-fractions containing the highest absorbance peaks were tested against reference sensitive moulds, and the extracts containing purified PgAFP were pooled from several batches. The protein concentration was quantified by the Lowry method (Lowry et al., 1951) and the stock solution was diluted in the elution buffer to the desired active concentration range $(1.17-75 \mu \mathrm{g} / \mathrm{mL})$ for the various assays.

\subsection{Proteomics}

\subsubsection{Protein extraction}

A. flavus CECT 2687 was cultured in triplicate in $50 \mathrm{~mL}$ PDB supplemented with $0.1 \mathrm{M} \mathrm{CaCl}_{2}$, at $25{ }^{\circ} \mathrm{C}$ for $24 \mathrm{~h}$ with shaking at $200 \mathrm{rpm}$, either in the presence $(10 \mu \mathrm{g} / \mathrm{mL})$ or absence of PgAFP, as previously described (Delgado et al., 2015b). Mycelia were harvested, filtered, washed and lysed as described by Carberry et al (2006). The lysed mycelia were centrifuged (10,000 g; $30 \mathrm{~min}$ ), the supernatant was precipitated with trichloroacetic acid/acetone (Carpentier et al., 2005), and analysed by the following two methods as previously described by (Delgado et al., 2015b).

\subsubsection{D-PAGE}

Resuspended extracts containing $250 \mu \mathrm{g}$ of protein were loaded onto Immobiline Dry strips (IPG strip; Amersham Biosciences, Uppsala, Sweden) in the pH range 4-7, followed by electrofocusing, and electrophoresis using the Protean Xi-II Cell (Bio-Rad Laboratories) as described by Carberry et al. (2006). Resulting gels $(n=5)$ were stained with colloidal Coomassie Blue (Sigma-Aldrich, St. Louis, MO, USA), scanned, normalized and analysed using Progenesis $^{\text {TM }}$ SameSpot software (TotalLab, Newcastle, UK).

Protein spots showing differences ( $p \leq 0.05$, fold change $\geq 1.5$ ) were excised, destained, sonicated, dehydrated, and trypsin in-gel digested according to Shevchenko et al. (2006). Then, the digest supernatants, containing tryptic peptides, were dried using a DNA Speed Vac Concentrator (Thermo Fischer Scientific, Austin, TX, USA), resuspended in $0.1 \%$ formic acid $(20 \mu \mathrm{L})$, and filtered through $0.22 \mu \mathrm{m}$ cellulose spin-filters (Agilent Technologies, Ireland).

The samples were analysed by a 6340 Model Ion Trap LC-Mass Spectrometer (Agilent Technologies, Ireland) using electrospray ionisation on a Zorbax 300 SB C-18 Nano-HPLC Chip $(150 \mathrm{~mm} \times 75 \mu \mathrm{m})$. The eluted peptides were ionized and analysed by mass spectrometry. $\mathrm{MS}^{\mathrm{n}}$ analysis was carried out on the three most abundant peptide precursor ions at each time point, as selected automatically by the mass spectrometer. MASCOT MS/MS Ion search, NCBI (National Centre for Biotechnology Information) database, FungiFun (Priebe et al., 2011) and KEGG (Kyoto Encyclopedia of Genes and Genome, www.genome.jp/kegg/) were used for protein identification and functional characterisation.

\subsubsection{Label-free comparative quantitative proteomic analysis}

The proteins precipitated from mycelial lysates were resuspended in $8 \mathrm{M}$ urea, reduced with dithiothreitol and alkylated with iodoacetamide (Owens et al., 2014). Samples $(n=3)$ were digested with trypsin combined with ProteaseMax surfactant, and desalted by application to C18 ZipTips ${ }^{\circledR}$ (Millipore, Darmstadt, Germany). One $\mu \mathrm{g}$ of each peptide mixture was analysed via a Thermo Scientific Q-Exactive mass spectrometer coupled to a Dionex RSLCnano. LC gradients ran from 4 to $35 \%$ B (A: $0.1 \%(v / v)$ formic acid, B: $80 \%(v)$ v) acetonitrile, $0.1 \%(\mathrm{v} / \mathrm{v})$ formic acid) over $2 \mathrm{~h}$, and data was collected using a Top15 method for MS/MS scans (Dolan et al., 2014; O'Keeffe et al., 2014; Owens et al., 2015). Comparative proteome abundance and data analysis was performed using MaxQuant software (Version 1.3.0.5) (Cox and Mann, 2008), with Andromeda used for database searching and Perseus (Version 1.4.1.3) used to organise the data. Carbamidomethylation of cysteines was set as a fixed modification, while oxidation of methionines and acetylation of N-terminals were set as variable modifications. The maximum peptide/protein false discovery rates were set to $1 \%$. The LFQ algorithm was used to generate normalized spectral intensities and infer relative protein abundance (Luber et al., 2010). Proteins that matched to a contaminants database or the reverse database were removed and proteins were only retained in final analysis if detected in at least two replicates from at least one treatment 
group. Quantitative analysis was performed using a $t$-test to compare pairs of samples, and proteins with significant change in abundance ( $p$ value $\leq 0.05$; fold change $\geq 2$ ) were included in the quantitative results. Qualitative analysis was also performed, to detect proteins that were found in at least 2 replicates of a particular treatment, but undetectable in the comparison sample group.

\subsection{Effect of cations on PgAFP activity}

The growth of PgAFP-treated A. flavus was evaluated in microtiter plate wells (DeltaLab, Rubí, Spain), containing $200 \mu \mathrm{L}$ of PDB supplemented with either $0.1 \mathrm{M}$ or $0.01 \mathrm{M} \mathrm{CaCl}_{2}$ and $10^{5}$ conidia per well incubated at $25^{\circ} \mathrm{C}$ without shaking. An additional plate containing only PDB was used as a control. Seven different two-fold dilutions of PgAFP, (75, 37.5, 18.75, 9.38, 4.69, 2.34, and to $1.17 \mu \mathrm{g} / \mathrm{mL}$ ), and a non-treated control were assayed. Six sample replicates for each combination of PgAFP treatment and cation concentration were processed. Optical density was measured at $550 \mathrm{~nm}$ every $24 \mathrm{~h}$ during $96 \mathrm{~h}$ in a microplate reader (TECAN Infinite M2000, Männendorf, Switzerland). Additionally, to test the effect of the monovalent $\mathrm{KCl}$ and the divalent $\mathrm{MgCl}_{2}$, two different plates were evaluated following the same procedure described herein, and containing 0.01 and $0.1 \mathrm{M}$ of $\mathrm{KCl}$ or $\mathrm{MgCl}_{2}$. These cation concentrations were chosen as they are representative of the levels found in cheese (Chekri et al., 2012). Given that $0.1 \mathrm{M} \mathrm{CaCl}_{2}$ was the concentration that abolished PgAFP antifungal ability, and this concentration is well within the levels present in cheese, the following assays were carried out using this concentration. Additionally, all of the following tests were also carried out with A. flavus grown in PDB with no calcium added as controls. All the micrographs from the same assay were taken with the same exposure.

\subsection{Metabolic tests}

To study the effect of $\mathrm{CaCl}_{2}$ on the metabolism of PgAFP-treated A. flavus, the following tests were carried out according to Delgado et al. (2015b). A. flavus was cultured in three replicate test tubes containing $200 \mu \mathrm{L}$ PDB supplemented with $0.1 \mathrm{M} \mathrm{CaCl}_{2}$ in either presence $(75 \mu \mathrm{g} / \mathrm{mL}$, to maximise the potential effect of this antifungal protein) or absence of PgAFP at $25{ }^{\circ} \mathrm{C}$ for $24 \mathrm{~h}$ without shaking. Additionally, to test the effect on membrane permeability on a whole range of PgAFP and calcium concentrations, seven PgAFP two-fold dilutions $(75,37.5,18.75,9.38,4.69,2.34$, and $1.17 \mu \mathrm{g} / \mathrm{mL}$ ) as well as $0.1 \mathrm{M}$ and $0.01 \mathrm{M} \mathrm{CaCl}_{2}$ were assayed in six sample replicate wells. To assess membrane permeability, A. flavus grown in microtiter plates with different $\mathrm{CaCl}_{2}$ and PgAFP concentrations were supplemented with $0.2 \mu \mathrm{M}$ SYTOX Green (Molecular Probes, Eugene, OR, USA). The emitted fluorescence was measured after 10,30 , and $210 \mathrm{~min}$.

To study the metabolic capability through viability staining, triplicate samples of mycelia were washed with $10 \mathrm{mM}$ HEPES pH 7.5 before staining with $100 \mu \mathrm{L}$ FUN-1 (Molecular Probes) for $30 \mathrm{~min}$ at $25^{\circ} \mathrm{C}$ according to Kaiserer et al. (2003). Stained hyphae were examined and photographed by fluorescence microscopy.

Membrane integrity was assessed with acridine orange/ ethidium bromide (AO/EB) double staining (Sigma-Aldrich). Triplicate samples of $A$. flavus cultures were stained with $4 \mu \mathrm{g} / \mathrm{mL}$ of AO/ $\mathrm{EB}$, incubated $30 \mathrm{~min}$ and washed twice with phosphate-buffered saline (PBS) to be observed by fluorescence microscopy.

To detect apoptotic events, triplicate samples of grown mycelia were stained with Apoptosis Detection Kit (Sigma-Aldrich) composed of Annexin V-fluorescein isothiocyanate/propidium iodide (AnV-FITC/PI), according to manufacturer's instructions.

\subsection{Chitin staining}

Conidia of $A$. flavus were inoculated in $10 \mathrm{~mL}$ PDB in a Petri dish containing a coverglass (Harris et al., 1994) and incubated at $25{ }^{\circ} \mathrm{C}$ for $24 \mathrm{~h}$ in the presence $(75 \mu \mathrm{g} / \mathrm{mL})$ and absence of PgAFP. Mycelia were washed, fixed and stained with fluorescent brightener 28 (Sigma-Aldrich) to visualize chitin by fluorescence microscopy as previously described (Delgado et al., 2015b). Additional batches with no $\mathrm{CaCl}_{2}$ added were also run as controls. All batches were prepared in triplicate.

\subsection{Localization of FITC-labelled PgAFP}

PgAFP was labelled with fluorescein isothiocyanate (FITC) by DareBio S.L. (Elche, Spain), as previously described (Delgado et al., 2015b). A. flavus was grown in triplicate PDB cultures, both with and without $0.1 \mathrm{M} \mathrm{CaCl}_{2}$, containing $20 \mu \mathrm{g} / \mathrm{mL} \mathrm{PgAFP-FITC} \mathrm{for}$ $24 \mathrm{~h}$ at $25^{\circ} \mathrm{C}$. Hyphae were washed twice with PBS and visualized by fluorescence microscopy.

\subsection{Effect of PgAFP on A. flavus in cheese}

One $\mathrm{cm}$ thick wedges of commercial Gouda type cheese of $10 \mathrm{~cm}^{2}$ were dipped in ethanol and dried in a laminar flow cabinet (Bio Flow II, Telstar, Tarrasa, Spain). Three sample wedges were separately placed in pre-sterilized containers after vapour-liquid equilibrium with a saturated $\mathrm{KCl}$ solution, to reach $\mathrm{a}_{\mathrm{w}}$ values of 0.84 , similar to those found in the rind at the final stage of cheese ripening (Rüegg and Blanc, 1981). Next, PgAFP was added in $200 \mu \mathrm{L}$ PBS to treated samples at two concentrations (18 and $35 \mu \mathrm{g} / \mathrm{cm}^{2}$ ) and left to dry in a flow cabinet. The non-treated batch received the same volume of PBS but with no PgAFP. Then, a volume of $100 \mu \mathrm{L}$ of a suspension of $A$. flavus spores was spread onto the upper surface of cheese wedges to reach c.a. $10^{5}$ conidia/ $\mathrm{cm}^{2}$. The containers were incubated for $96 \mathrm{~h}$ and growth of the resulting mycelia was assessed. This test was performed in triplicate. Water activity $\left(a_{w}\right)$ was determined in cheese wedges by a LabMASTER-aw instrument (Novasina AG, Lachen, Switzerland) both before inoculation and after $96 \mathrm{~h}$ incubation. This test was run in three independent trials.

\subsection{Statistical analysis}

Statistical analyses were performed with IBM SPSS v.22 (www03.ibm.com/software/products/es/spss-stats-standard). Growth inhibition and membrane permeability data were tested for normality (Kolmogorov-Smirnov with Lilliefors correction) and homoscedasticity (Levene's test). These data were non-normally distributed, then mean values were compared using nonparametric Kruskal-Wallis test. To compare treatments in pairs, Mann-Whitney $U$ test was applied $(p \leq 0.05)$.

\section{Results}

\subsection{Antifungal activity of PgAFP on cheese}

To study the potential application of PgAFP against A. flavus in the dairy industry, the antifungal activity of 18 and $35 \mu \mathrm{g} / \mathrm{cm}^{2}$ PgAFP was tested on cheese wedges simulating common ripening conditions. The $\mathrm{a}_{\mathrm{w}}$ value of cheese samples was $0.940( \pm 0.004 \mathrm{SD})$ at the time of inoculation and decreased to $0.910( \pm 0.003$ SD), 0.883 $( \pm 0.003 \mathrm{SD})$, and $0.844( \pm 0.002 \mathrm{SD})$ after 4,8 , and 15 days of incubation, respectively. Growth of $A$. flavus on cheese treated with any of the two PgAFP concentrations was extensive (Fig. 1), indicating that PgAFP did not affect $A$. flavus growth on cheese. 


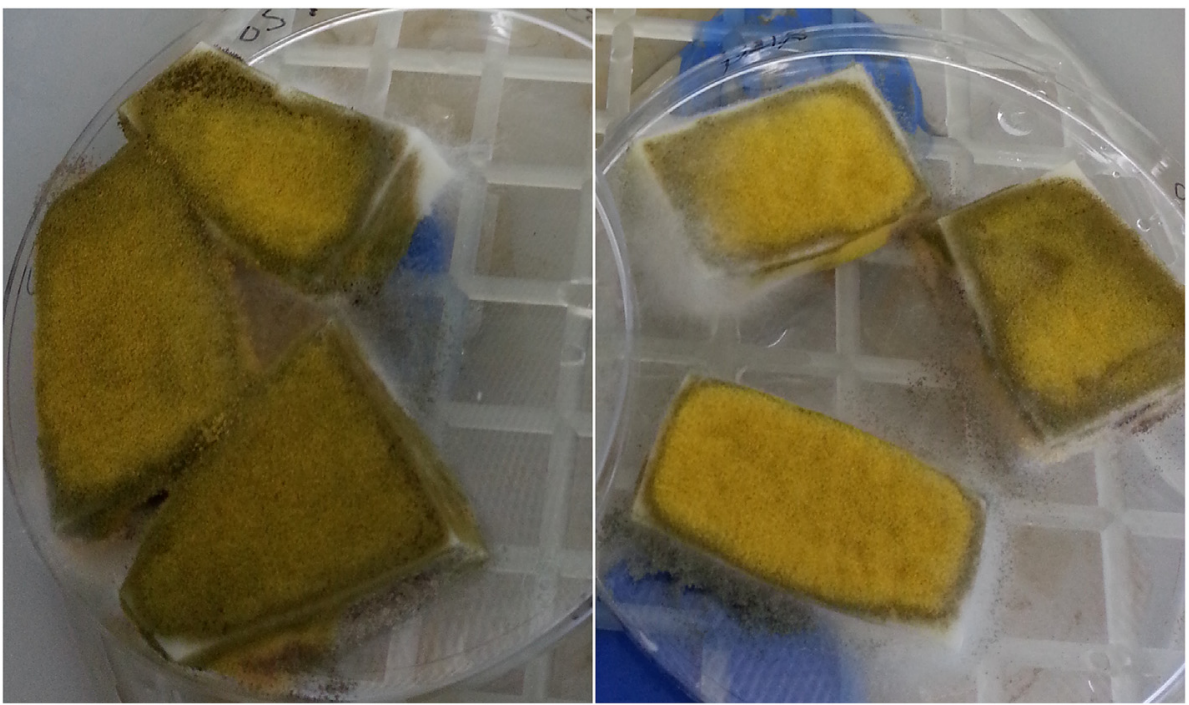

Fig. 1. Exuberant growth of A. flavus in cheese wedges treated with $18 \mu \mathrm{g} / \mathrm{cm}^{2}$ (left) and $35 \mu \mathrm{g} / \mathrm{cm}^{2}$ PgAFP (right).

\subsection{Effect of cations on PgAFP antifungal activity}

The effect of calcium, magnesium and potassium on the antifungal activity of PgAFP against A. flavus was studied in PDB cultures (Fig. 2). The maximum O.D. reached at $96 \mathrm{~h}$ in control cultures, without PgAFP, was affected by $\mathrm{KCl}$ and $\mathrm{CaCl}_{2}$, with lower levels of growth observed with $\mathrm{KCl}(p \leq 0.05)$ and higher with $\mathrm{CaCl}_{2}$ $(p \leq 0.05)$. Control cultures, with no cations added, confirmed that $18.75 \mu \mathrm{g} / \mathrm{mL}$ PgAFP reduced A. flavus growth over $50 \%$ at $96 \mathrm{~h}$. With either $0.01 \mathrm{M}$ (data not shown) or $0.1 \mathrm{M} \mathrm{KCl}$, PgAFP antifungal activity was essentially unaffected (Fig. 2). Similarly, $0.01 \mathrm{M} \mathrm{MgCl}_{2}$ did not have a substantial impact on PgAFP antifungal activity, whereas $0.1 \mathrm{M} \mathrm{MgCl}_{2}$ lowered PgAFP effect, so that 50\% growth inhibition was not reached at $96 \mathrm{~h}$ incubation even at the highest PgAFP concentration tested $(p>0.05)$. The strongest effect was obtained with $\mathrm{CaCl}_{2}$; with $0.01 \mathrm{M} \mathrm{CaCl}_{2}, 37.5 \mu \mathrm{g} / \mathrm{mL} \mathrm{PgAFP}$ was required to reach $50 \%$ A. flavus growth inhibition at $96 \mathrm{~h}$, but with $0.1 \mathrm{M} \mathrm{CaCl}_{2}$ no growth inhibition was obtained even with $75 \mu \mathrm{g} / \mathrm{mL}$ PgAFP $(p>0.05)$.

\subsection{PgAFP localization and membrane permeability}

Given that $0.1 \mathrm{M} \mathrm{CaCl}_{2}$ abolished PgAFP antifungal activity, and this concentration is well within the range of calcium levels in ripened cheese (Chekri et al., 2012), only $\mathrm{CaCl}_{2}$ was tested for the remaining assays. To determine whether calcium influences PgAFP
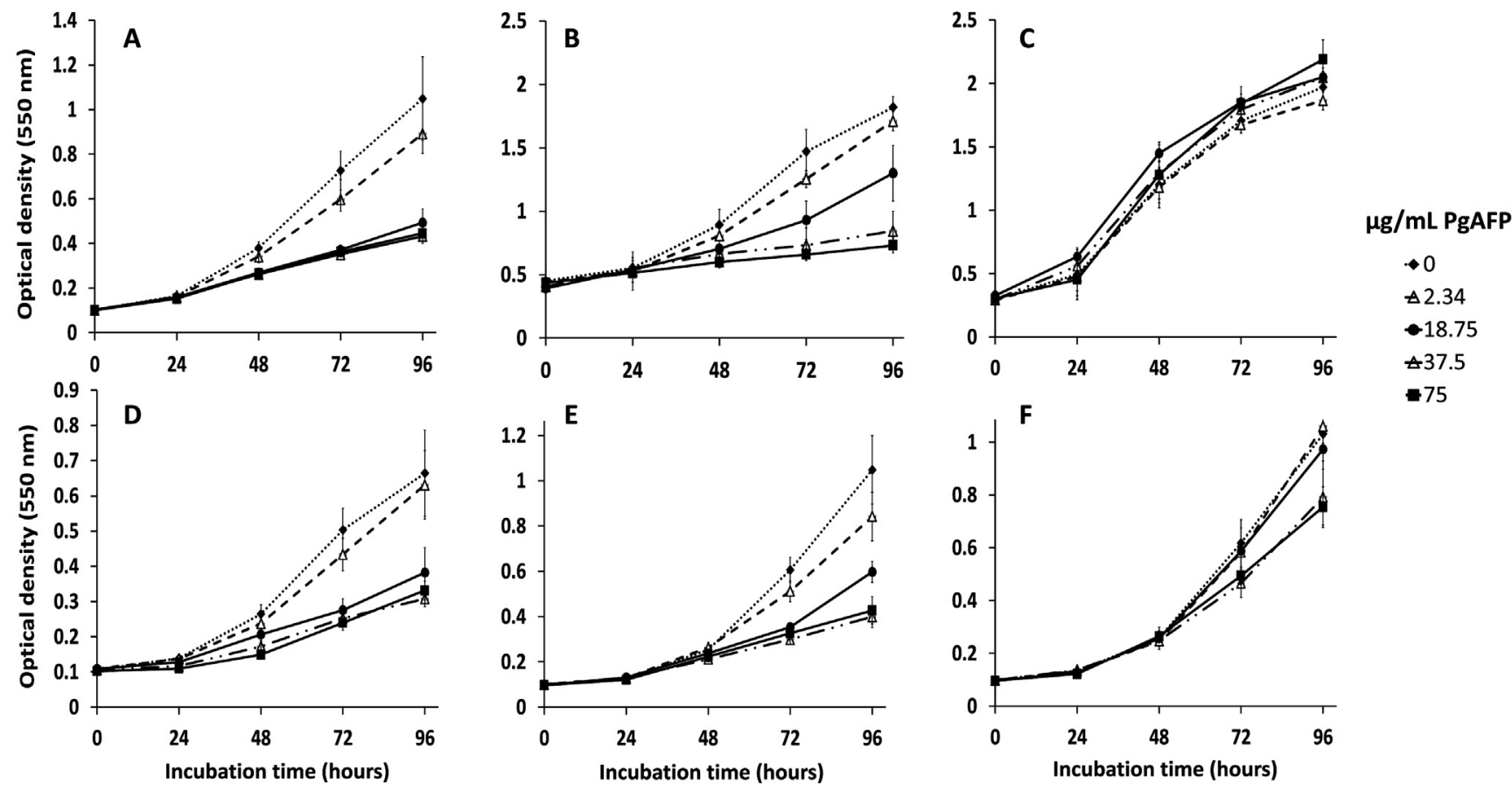

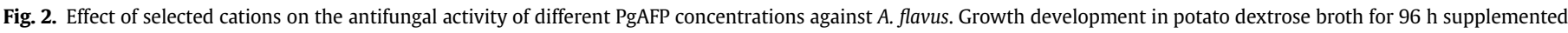
with (A) no cations, (B) $0.01 \mathrm{M} \mathrm{CaCl}_{2}$, (C) $0.1 \mathrm{M} \mathrm{CaCl}_{2}$, (D) $0.1 \mathrm{M} \mathrm{KCl}$, (E) $0.01 \mathrm{M} \mathrm{MgCl}_{2}$ and (F) $0.1 \mathrm{M} \mathrm{MgCl}_{2}$. Vertical bars represent standard deviation of the mean. 
localization, A. flavus grown in PDB supplemented with $0.1 \mathrm{M} \mathrm{CaCl}_{2}$ was treated with FITC-labelled PgAFP. The FITC-labelled PgAFP was visualized bound to the outer layer of $A$. flavus hyphae, but unlike the $\mathrm{CaCl}_{2}$-free control, it was unable to penetrate into the cytoplasm (Fig. 3). The antifungal activity of FITC-labelled PgAFP was evaluated against $A$. flavus in $\mathrm{CaCl}_{2}$-free PDB, showing similar levels to those of non FITC-labelled PgAFP (data not shown).

To assess the influence of $\mathrm{CaCl}_{2}$ on $A$. flavus permeabilization by PgAFP, the SYTOX Green uptake test was used. With no calcium added, fluorescence values increased as PgAFP concentration increased from 0 to $4.69 \mu \mathrm{g} / \mathrm{mL}(p \leq 0.05)$ and then progressively decreased from 9.38 to $75 \mu \mathrm{g} / \mathrm{mL}$ (Fig. 4), as shown previously (Delgado et al., 2015b). With $0.01 \mathrm{M} \mathrm{CaCl}_{2}$, a slightly higher PgAFP concentration $(18.75 \mu \mathrm{g} / \mathrm{mL})$ was required to reach the highest fluorescence values, as opposed to $4.69-9.38 \mu \mathrm{g} / \mathrm{mL}$ PgAFP in the control batch without $\mathrm{CaCl}_{2}$. In addition, the decrease of fluorescence obtained at the highest PgAFP concentrations $(37.5-75 \mu \mathrm{g} /$ $\mathrm{mL}$ ) with $0.01 \mathrm{M} \mathrm{CaCl}_{2}$ was even more pronounced than that obtained with 0 or $0.1 \mathrm{M} \mathrm{CaCl}_{2}$. On the other hand, high fluorescence values were obtained when $A$. flavus was cultured in $0.1 \mathrm{M} \mathrm{CaCl}_{2}$ PDB, even when no PgAFP was present. Therefore, A. flavus permeability was strongly increased by either PgAFP or $0.1 \mathrm{M} \mathrm{CaCl}_{2}$. However, PgAFP at any concentration barely increased A. flavus permeability in $0.1 \mathrm{M} \mathrm{CaCl}_{2} \mathrm{PDB}$ (Fig. 4).

\subsection{Effect of PgAFP in presence of calcium on protein abundance}

No differences $(p>0.05)$ in A. flavus mycelia weight were noted between PgAFP-treated and untreated samples grown in PDB supplemented with $0.1 \mathrm{M} \mathrm{CaCl}_{2}$. 2D-PAGE comparative proteomic analysis revealed 19 unique proteins from 24 spots, whose relative abundance was altered in treated samples (Supplementary Material Table S1). In the PgAFP-treated batch, the relative abundance was from 1.5 to 1.6 fold higher for 7 proteins including Gprotein complex $\beta$ subunit $\mathrm{CpcB}$, whilst 12 proteins, identified from 17 spots were found between 1.6 and 2.5 fold lower. Among proteins found in reduced quantities, three isoforms of elongation factor 3, and two isoforms each of aminopeptidase, glycogen branching enzyme GbeA, and aldehyde dehydrogenase AldA were identified. The two spots found from AldA were observed with different molecular masses and isoelectric points, possibly due to breakdown and side-chain deamination.

The label-free quantitative analysis in PDB supplemented with $0.1 \mathrm{M} \mathrm{CaCl}_{2}$ revealed a total of 1651 proteins, 195 of them showed significantly altered abundance due to PgAFP-treatment (Supplementary Material Table S2). A total of 125 proteins were detected at elevated levels in PgAFP-treated A. flavus. Among them, 90 proteins were found in a higher abundance, from 2 to 53 fold

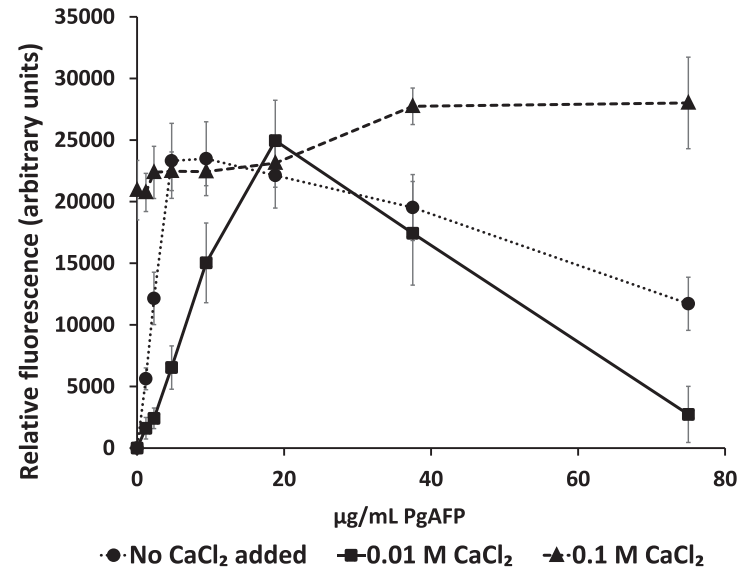

Fig. 4. Effect of $0.01 \mathrm{M}$ and $0.1 \mathrm{M} \mathrm{CaCl}_{2}$ on membrane permeability of A. flavus treated with PgAFP $(0-75 \mu \mathrm{g} / \mathrm{mL})$ at $210 \mathrm{~min}$ after SYTOX Green addition. Vertical bars represent standard deviation of the mean.

(quantitative results), and 35 proteins were exclusively detected in the treated batch (qualitative results). In addition, 70 proteins were detected at lower abundance in PgAFP-treated samples, 32 of which were found in lower abundance, from 2.1 to 703 fold, and the 38 remaining were not detected in the treated batch.

According to KEGG, 13 out of the 70 proteins found in lower amount following PgAFP treatment were involved in metabolic pathways and biosynthesis of secondary metabolites. In contrast, among the proteins whose abundance was higher in PgAFP-treated A. flavus, 23 of them were related with ribosome and 11 with spliceosome. From the proteins of the oxidative stress-related glutathione metabolism, glutathione S-transferase and $\gamma$-glutamyltranspeptidase $(\gamma-\mathrm{GT})$ showed higher relative abundance in PgAFP-treated samples (Supplementary Material Table S2). In addition, $\mathrm{G}$-protein complex $\beta$ subunit $\mathrm{CpcB}$, recently described as related to the mechanism of action of antifungal proteins (Delgado et al., 2015b), was also increased in PgAFP treated samples (Supplementary Material Table S1). All 19 proteins showing relative abundance altered in 2D-PAGE were found in the label-free proteomic assay, but showing different fold change in both methods.

\subsection{Effect on metabolic capability and chitin deposition}

The metabolic capability of $A$. flavus grown with $0.1 \mathrm{M}$ of $\mathrm{CaCl}_{2}$ was not influenced by PgAFP, as shown by FUN-1 staining. Intravacuolar red spots were present in both PgAFP-treated and nontreated batches, revealing a normal metabolic capability (Fig. 5).

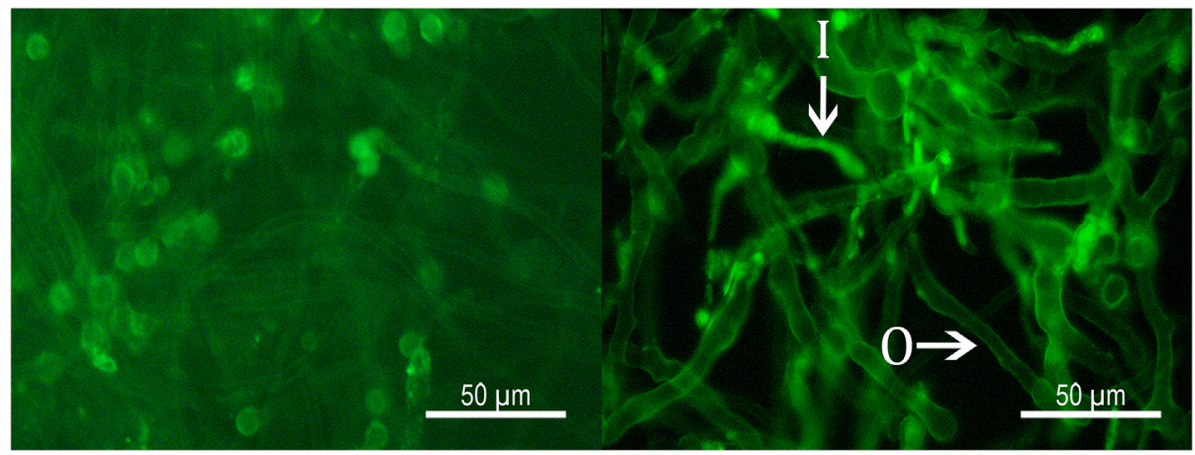

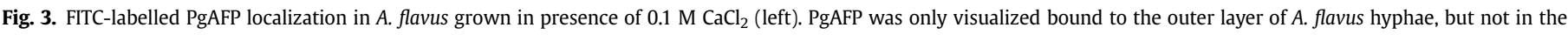

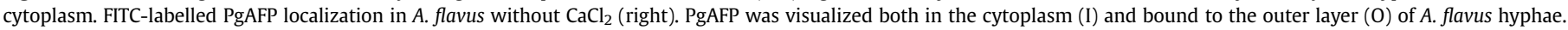




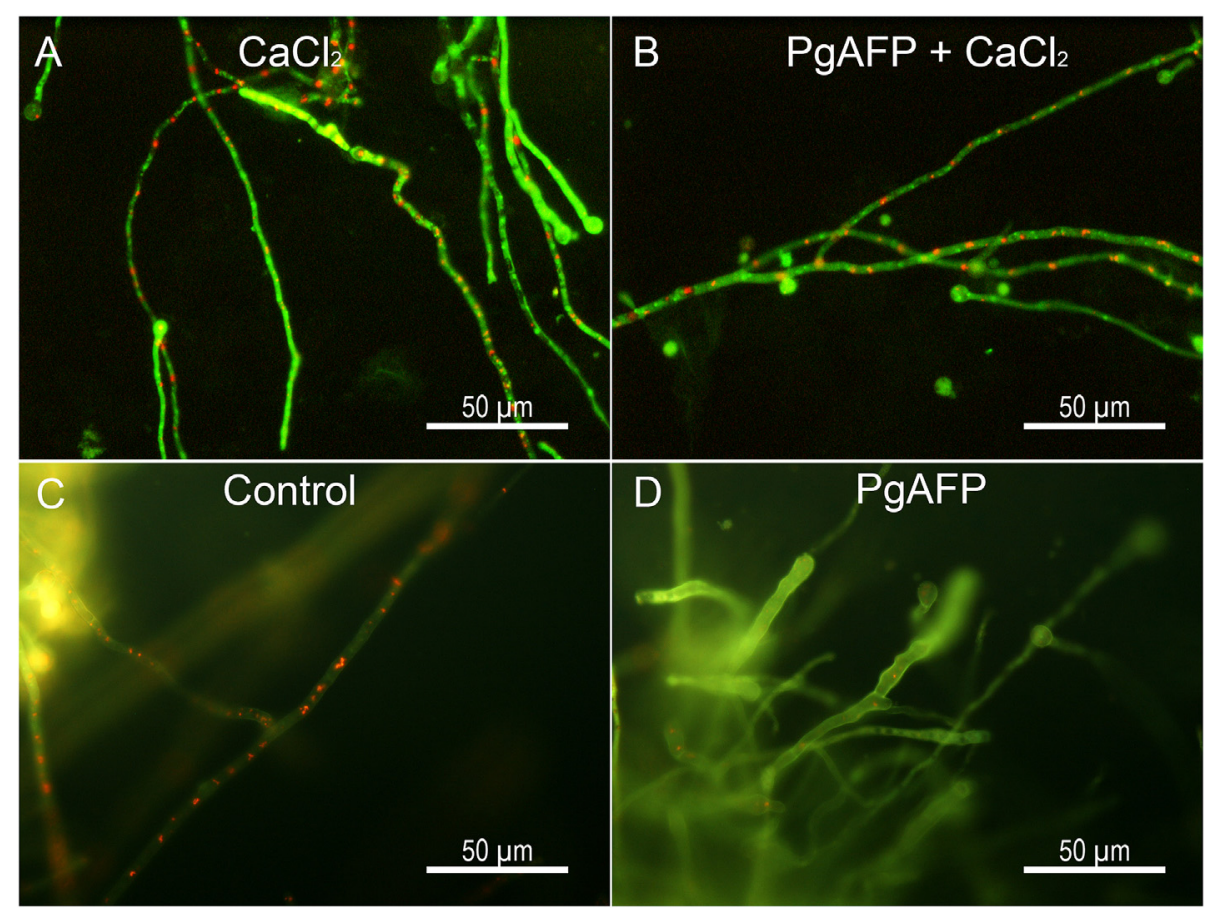

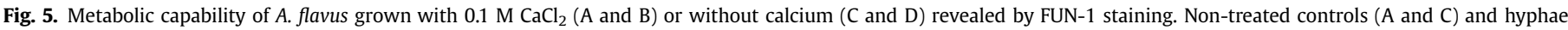

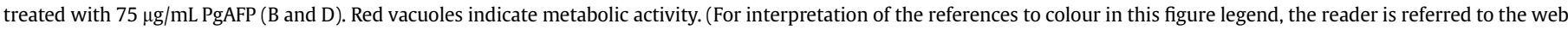
version of this article.)

In the absence of added calcium, non-treated control also displayed intra-vacuolar red spots, whereas A. flavus grown with $75 \mu \mathrm{g} / \mathrm{mL}$ PgAFP scarcely showed red spots.

Chitin deposition has been described as a successful response against PgAFP in resistant P. polonicum (Delgado et al., 2016). Staining with fluorescent brightener 28 showed that $0.1 \mathrm{M} \mathrm{CaCl}_{2}$ made no obvious difference to chitin deposition in non PgAFPtreated A. flavus, as compared to the altered chitin deposition in PgAFP-treated samples (Fig. 6). However, $0.1 \mathrm{M} \mathrm{CaCl}_{2}$ allowed maintenance of similar chitin levels to those observed in the non PgAFP-treated control. As expected, PgAFP-treated controls with no calcium added displayed alterations (Figs. 5 and 6), but non-treated

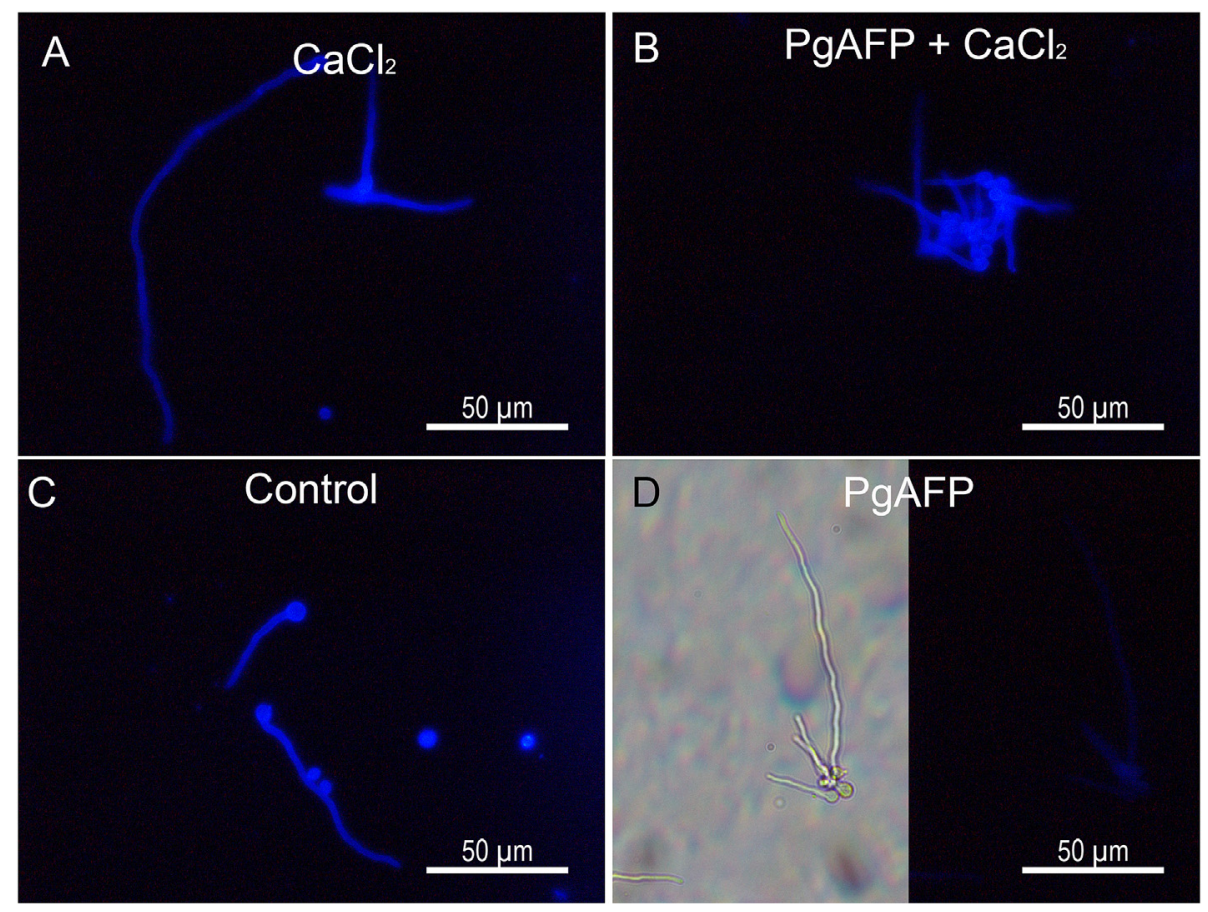

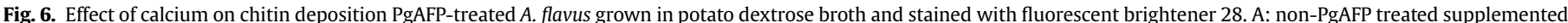

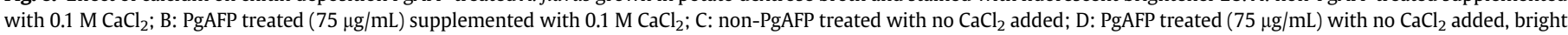
field (left) and fluorescence observation (right). 
A. flavus remaining unaltered.

\subsection{Effect on oxidative status and viability}

Hyphal viability and apoptotic or necrotic processes of A. flavus grown in $0.1 \mathrm{M} \mathrm{CaCl}_{2} \mathrm{PDB}$ were studied with $\mathrm{AO} / \mathrm{EB}$ double staining and AnV-FITC/PI staining, respectively. The AO/EB double staining showed a predominant green colour both in PgAFP-treated and untreated samples due to AO but not EB staining (Fig. 7). This implies that $0.1 \mathrm{M} \mathrm{CaCl}_{2}$ maintains the viability of PgAFP-treated A. flavus. Moreover, both treated and non-treated batches were not stained by AnV-FITC/PI (Fig. 8), implying that PgAFP did not induce apoptosis or necrosis in cultures containing $0.1 \mathrm{M} \mathrm{CaCl}_{2}$. Relevantly, PgAFP-treated controls with no calcium added displayed alterations (Figs. 7 and 8), whilst non-treated A. flavus remained unaltered.

\section{Discussion}

The capacity of just $5 \mu \mathrm{g} / \mathrm{cm}^{2}$ PgAFP to reduce A. flavus counts was demonstrated on dry-fermented sausage (Delgado et al., 2015a). Such effect would also be useful in ripened cheese, but the high calcium levels could interfere with PgAFP activity. The treatment with PgAFP was not effective in reducing A. flavus growth on cheese (Fig. 1). Both dry-fermented sausage and cheese assays were performed under identical environmental conditions of $25^{\circ} \mathrm{C}$, with constant relative humidity maintained by means of a saturated $\mathrm{KCl}$ solution (Delgado et al., 2015a). Environmental factors such as $\mathrm{pH}$ or $\mathrm{NaCl}$ concentration may affect PgAFP antifungal activity. However this activity appears not to be affected by monovalent cations, and withstands a broad range of $\mathrm{pH}$ values (Delgado et al., 2015a). Given that the PgAFP concentrations tested on cheese were up to 7-fold higher than that effective on the sausage, the lack of PgAFP activity has to be related to cheese composition. Other researchers have proven that concentrations of mono- and divalent cations over 20-100 mM suppress the inhibitory activity of other antifungal proteins in culture media (Galgóczy et al., 2013; Kaiserer et al., 2003; Theis et al., 2003; Thevissen et al., 1999, 1996). Average calcium, magnesium, and potassium concentrations in cheese are c.a. $0.14,0.013$, and $0.03 \mathrm{M}$, respectively (Chekri et al., 2012). Given that these concentrations are higher than those suppressing the activity of other antifungal proteins, the effect of each of these minerals on PgAFP activity against $A$. flavus was investigated.

The antifungal capability of all concentrations of PgAFP tested against A. flavus in PDB was strongly reduced with $0.1 \mathrm{M} \mathrm{CaCl}_{2}$ or $\mathrm{MgCl}_{2}$ (Fig. 2), whereas only the antifungal effect of low PgAFP concentrations was prevented with $0.01 \mathrm{M}$ concentrations of these divalent cations. For the monovalent potassium salt, 0.01 and $0.1 \mathrm{M}$ only slightly reduced PgAFP antifungal activity. These results infer that the lack of activity of PgAFP on A. flavus observed in cheese could be explained solely by the calcium content.

Similar results have been reported for AFP, PAF, NFAP, and plant defensins, where the antifungal activity was significantly counteracted by the presence of high concentrations of monovalent cations or $\mathrm{MgCl}_{2}$ (Galgóczy et al., 2013; Kaiserer et al., 2003; Theis et al., 2003; Thevissen et al., 1999). This loss of antifungal activity has been explained by a saturation of the cellular target of antifungal proteins with cations, making the target site no longer accessible for the antifungal protein (Theis et al., 2003). Small, basic, and cysteine-rich antifungal proteins from moulds have a positive net charge, and cations could interfere by competing for putative binding sites at the fungal cell surface (Martín-Urdiroz et al., 2009; Marx, 2004).

FITC-labelled PgAFP was located both bound to outer layer and intracellularly in A. flavus grown in $\mathrm{PDB}$ with no $\mathrm{CaCl}_{2}$ added (Delgado et al., 2015b). However, when A. flavus was grown in $0.1 \mathrm{M}$ $\mathrm{CaCl}_{2}$ PDB, FITC-labelled PgAFP was only found at the outer layer and not internalized (Fig. 3), implying that membrane integrity was
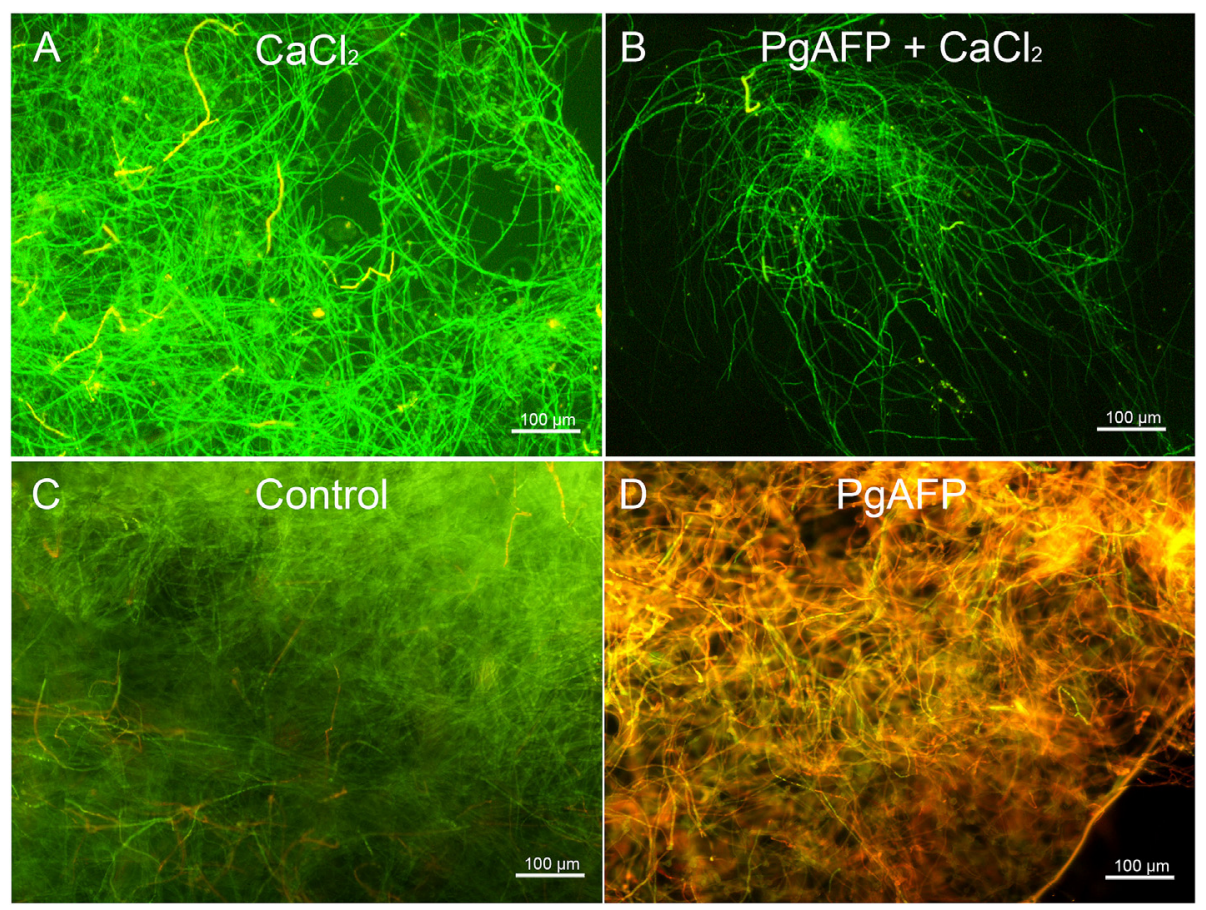

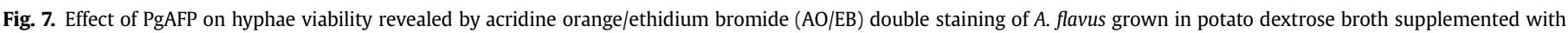

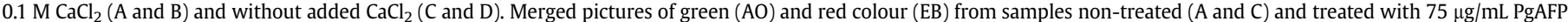

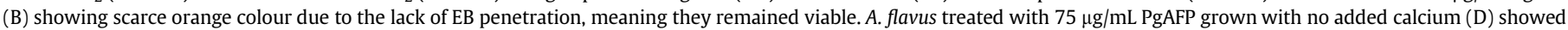

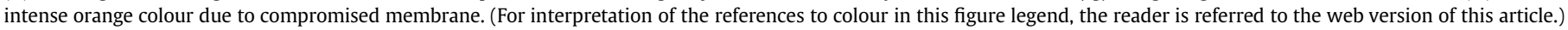



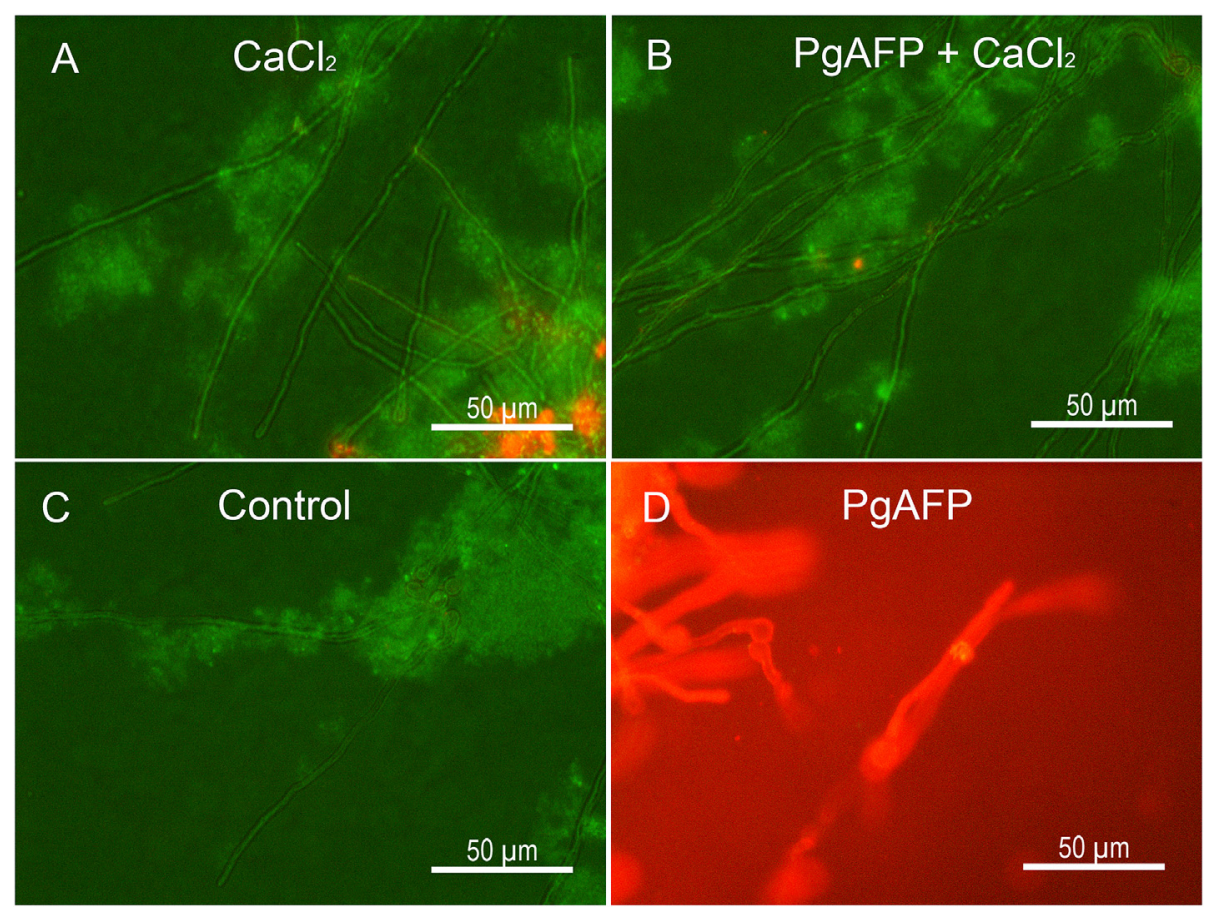

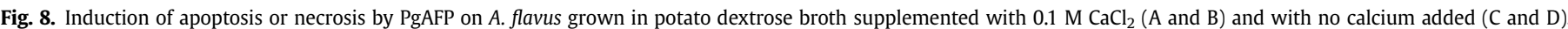

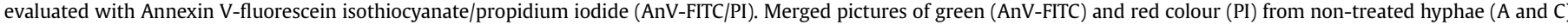

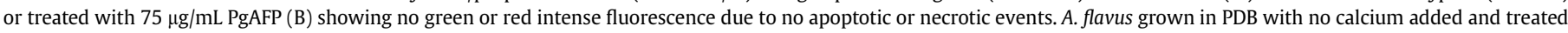

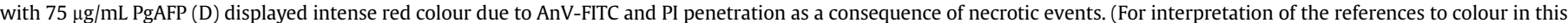
figure legend, the reader is referred to the web version of this article.)

not compromised. When grown in $0.1 \mathrm{M} \mathrm{CaCl}_{2} \mathrm{PDB}$, A. flavus permeability to SYTOX Green increased to the maximum level provoked by PgAFP with no calcium added (Fig. 4), similarly to the pattern obtained in Aspergillus niger with $1 \mathrm{M} \mathrm{CaCl}_{2}$ (Gomaa et al., 2013). When A. flavus was grown with both PgAFP and $0.1 \mathrm{M}$ $\mathrm{CaCl}_{2}$, no further increase in permeability was observed. Thus, all the above results support that calcium ions did not prevent PgAFP from binding to the outer layer. Moreover, no other detrimental effect was observed in A. flavus at any PgAFP concentration through metabolic capability or viability, as evaluated by FUN-1, AO/EB, and AnV-FITC/PI staining. Therefore, calcium may have rendered the putative membrane targets non-accessible to PgAFP. Nonetheless, comparative proteomics disclosed remarkable changes in fungal metabolism triggered by PgAFP when grown in $0.1 \mathrm{M} \mathrm{CaCl}_{2}$ PDB.

A total of 19 and 195 proteins showed altered relative abundances by $\mathrm{CaCl}_{2}$ according to 2D-PAGE and label-free proteomics, respectively. The difference between the number of proteins obtained by these two methods have been explained as a consequence of 2D-PAGE being able to separate isoforms and posttranslational modifications but only within a limited $\mathrm{pH}$ range, whereby the whole proteome is not represented (Görg et al., 2009, 2004). In contrast, label-free proteomics is not able to separate isoforms and compares the total quantity of the protein, but has a higher coverage with regard to $\mathrm{pH}$ and molecular mass range. Hence, the differences observed in relation to the fold change for any given protein seem to be related to the involvement of isoforms or post-translational modifications, as well as the different threshold used by both methods (Delgado et al., 2015b, 2016).

The comparative proteomic assays for A. flavus in the presence of $\mathrm{CaCl}_{2}$ revealed a large number of proteins affected by PgAFP exposure. According to KEGG, proteins related to ribosome and spliceosome accounted for $27 \%$ of the proteins with altered relative amount. The relative quantities for most proteins of these two groups were higher in PgAFP-treated samples. Similar results were obtained for ribosomal and spliceosomal proteins when PgAFP was applied to cultures grown in absence of $\mathrm{CaCl}_{2}$ of both A. flavus (Delgado et al., 2015b) and the PgAFP-resistant P. polonicum (Delgado et al., 2016). Given that the increase of these two groups of proteins is a common response to PgAFP in both sensitive and resistant moulds, it does not seem to be crucial to discriminate when inhibition is overcome.

The mechanism of action of antifungal proteins has been described through different inter-related metabolic pathways, including oxidative stress, cell wall integrity (CWI) pathway, and chitin synthesis (Delgado et al., 2015b; Hagen et al., 2007; Marx et al., 2008). Some proteins involved in these pathways showed higher relative abundance in response to PgAFP in A. flavus grown in $0.1 \mathrm{M} \mathrm{CaCl}_{2} \mathrm{PDB}$, including G-protein complex $\beta$ subunit $\mathrm{CpcB}$, and proteins of the oxidative stress-related glutathione pathway, namely glutathione S-transferase and $\gamma$-GT. These proteome changes would rule out the blockage of PgAFP receptors as the only protective mechanism of $\mathrm{Ca}^{2+}$ in A. flavus, suggesting a survival reaction of $A$. flavus to the antifungal protein as discussed below.

No significant differences were found in the protein Rho GTPase Rho1 between PgAFP-treated and untreated $A$. flavus grown with $0.1 \mathrm{M} \mathrm{CaCl}_{2}$ (Supplementary Material Table S2). Lower Rho1 levels have been identified among the main factors involved in the inhibition of $A$. flavus by PgAFP in PDB with no $\mathrm{CaCl}_{2}$ added (Delgado et al., 2015b), whereas higher levels of Rho1 play a key role in increasing chitin deposition in PgAFP-treated P. polonicum, likely activating Pkc/Mpk pathway (Delgado et al., 2016). The unaltered chitin deposition in PgAFP-treated A. flavus grown with $\mathrm{CaCl}_{2}$ (Fig. 6) can be related by the substantially unaffected quantity of Rho1 and any other protein related to the CWI pathway.

Extracellular calcium can act as a stress signal in moulds that increases the intracellular $\mathrm{Ca}^{2+}$ concentration and lead to the 
activation of calmodulin, which in turn can activate calcineurin (Thewes, 2014). Calcineurin is a heterodimer comprised of subunits $\mathrm{A}$ and $\mathrm{B}$. Calcineurin $\mathrm{Ca}^{2+}$-binding regulatory subunit $\mathrm{CnaB}$ is essential for activation of the calcineurin A (calmodulin-binding catalytic subunit $\mathrm{CnaA}$ ) that is important in stress adaptation (Juvvadi et al., 2003). Calcineurin regulates the transcription factor CRZ1A, that induces transcription of chitin synthases chs A and chsC in filamentous fungi, but can also control chitin synthases themselves (Fortwendel et al., 2010) or interact genetically with the endogenous calcineurin regulators, calcipressins (Soriani et al., 2008). Activation of calmodulin-calcineurin signalling by high cytosolic $\mathrm{Ca}^{2+}$ concentration leads to A. fumigatus growth in presence of antifungal drugs (Juvvadi et al., 2015). The $0.1 \mathrm{M} \mathrm{CaCl}_{2}$ level specifically led to the higher relative abundance of $\mathrm{CnaB}$ in both PgAFP-treated and untreated A. flavus (Supplementary Material Table S1) (Delgado et al., 2015b). Thus, the protective effect of high calcium levels in A. flavus can be mediated by increased CnaB.

$G$ protein $\mathrm{CpcB}$ may also play a central role in vegetative growth and development, as its deficiency severely impaired cellular growth in Aspergilli (Kong et al., 2013). The lower quantity of CpcB has been related to apoptosis signalling in PgAFP-treated A. flavus (Delgado et al., 2015b). In the present work, the higher relative abundance of $\mathrm{CpcB}$ subunit was not accompanied by apoptotic or necrotic signals in PgAFP-treated A. flavus grown in $0.1 \mathrm{M} \mathrm{CaCl}_{2}$. Therefore, $\mathrm{CpcB}$ can be considered a key factor in promoting or arresting apoptotic events by PgAFP, leading to sensitivity or resistance, respectively. The protective mechanism mediated by $\mathrm{CpcB}$ in A. flavus grown with calcium seems to be based on the modulation of glutathione that would impact on reactive oxygen species (ROS) levels.

The proteins related to glutathione metabolism have been shown to be important in the maintenance of the redox status upon oxidative stress in fungi (Kang et al., 2005; Park et al., 2005, 2004; Springael and Penninckx, 2003). Thus, the higher relative abundance of these proteins could be related to the successful response of A. flavus to PgAFP in the calcium-enriched culture medium. No direct link between increased calcium levels and induction of proteins involved in glutathione metabolism can be established at present. However, it is plausible that a primary adaptive response mediated by $\mathrm{CnaB}$ or $\mathrm{CpcB}$ allow the time for $A$. flavus to develop an effective response to oxidative stress, leading to increased levels of proteins involved in the glutathione pathway. To overcome the protective role of divalent cations against antifungal proteins, PgAFP treatment could be combined with other preservatives showing complementary mechanisms of action. Future studies with extended incubation time will also help to assess the effect of PgAFP on mould growth and mycotoxin production in ripened cheese.

\section{Conclusion}

This work does not support that occlusion of specific receptors is responsible for the observed protective role of divalent cations in preventing the antifungal effect of PgAFP on A. flavus. Conversely, the data indicate that $A$. flavus resistance to PgAFP in $0.1 \mathrm{M} \mathrm{CaCl}_{2}$ is primarily mediated by an increased $\mathrm{CnaB}, \mathrm{CpcB}$ and $\gamma$-GT, which would enhance the response to oxidative stress and impede apoptosis. Understanding the mechanism of resistance against PgAFP can be useful to design strategies aiming to prevent growth of mycotoxigenic moulds in foods with high levels of divalent cations.

\section{Acknowledgements}

This work was supported by the Spanish Ministry of Education and Science, Ministry of Economy and Competitiveness and FEDER (AGL2010-21623, AGL2013-45729-P). Josué Delgado was recipient of FPI grants from the Spanish Ministry of Education and Science (BES-2011-043422 and EEBB-I-13-06900). Rebecca A. Owens was funded by a 3U Partnership Award (http://www.3UPartnership.ie/). Mass spectrometry facilities were funded by Science Foundation Ireland (Q-Exactive; Grant number: 12/RI/2346(3)) and the Irish Higher Education Authority (Agilent Ion Trap 6340). Fungal research in the Doyle laboratory is funded by Science Foundation Ireland grant number PI/11/1188.

\section{Appendix A. Supplementary data}

Supplementary data related to this article can be found at http:// dx.doi.org/10.1016/j.fm.2017.03.015.

\section{References}

Acosta, R., Rodríguez-Martín, A., Martín, A., Núñez, F., Asensio, M.A., 2009. Selection of antifungal protein-producing molds from dry-cured meat products. Int. J. Food Microbiol. 135, 39-46. http://dx.doi.org/10.1016/ j.ijfoodmicro.2009.07.020.

Bernáldez, V., Rodríguez, A., Martín, A., Lozano, D., Córdoba, J.J., 2014. Development of a multiplex qPCR method for simultaneous quantification in dry-cured ham of an antifungal-peptide Penicillium chrysogenum strain used as protective culture and aflatoxin-producing moulds. Food Control 36, 257-265. http:// dx.doi.org/10.1016/j.foodcont.2013.08.020.

Binder, U., Bencina, M., Eigentler, A., Meyer, V., Marx, F., 2011. The Aspergillus giganteus antifungal protein AFPNN5353 activates the cell wall integrity pathway and perturbs calcium homeostasis. BMC Microbiol. 11, 209. http:// dx.doi.org/10.1186/1471-2180-11-209.

Binder, U., Chu, M., Read, N.D., Marx, F., 2010. The antifungal activity of the Penicillium chrysogenum protein PAF disrupts calcium homeostasis in Neurospora crassa. Eukaryot. Cell 9, 1374-1382. http://dx.doi.org/10.1128/EC.00050-10.

Cagas, S.E., Jain, M.R., Li, H., Perlin, D.S., 2011. Profiling the Aspergillus fumigatus proteome in response to caspofungin. Antimicrob. Agents Chemother. 55, 146-154. http://dx.doi.org/10.1128/AAC.00884-10.

Carberry, S., Neville, C.M., Kavanagh, K.A., Doyle, S., 2006. Analysis of major intracellular proteins of Aspergillus fumigatus by MALDI mass spectrometry: identification and characterisation of an elongation factor $1 \mathrm{~B}$ protein with glutathione transferase activity. Biochem. Biophys. Res. Commun. 341, 1096-1104. http://dx.doi.org/10.1016/j.bbrc.2006.01.078.

Carpentier, S.C., Witters, E., Laukens, K., Deckers, P., Swennen, R., Panis, B., 2005. Preparation of protein extracts from recalcitrant plant tissues: an evaluation of different methods for two-dimensional gel electrophoresis analysis. Proteomics 5, 2497-2507. http://dx.doi.org/10.1002/pmic.200401222.

Chekri, R., Noël, L., Millour, S., Vastel, C., Kadar, A., Sirot, V., Leblanc, J.C., Guérin, T., 2012. Calcium, magnesium, sodium and potassium levels in foodstuffs from the second French Total Diet Study. J. Food Compos. Anal. 25, 97-107. http:// dx.doi.org/10.1016/j.jfca.2011.10.005.

Cox, J., Mann, M., 2008. MaxQuant enables high peptide identification rates, individualized p.p.b.-range mass accuracies and proteome-wide protein quantification. Nat. Biotechnol. 26, 1367-1372. http://dx.doi.org/10.1038/nbt.1511.

Delgado, J., Acosta, R., Rodríguez-Martín, A., Bermúdez, E., Núñez, F., Asensio, M.A., 2015a. Growth inhibition and stability of PgAFP from Penicillium chrysogenum against fungi common on dry-ripened meat products. Int. J. Food Microbiol. 205, 23-29. http://dx.doi.org/10.1016/j.ijfoodmicro.2015.03.029.

Delgado, J., Owens, R.A., Doyle, S., Asensio, M.A., Núñez, F., 2015b. Impact of the antifungal protein PgAFP from Penicillium chrysogenum on the protein profile in Aspergillus flavus. Appl. Microbiol. Biotechnol. 99, 8701-8715. http://dx.doi.org/ 10.1007/s00253-015-6731-X.

Delgado, J., Owens, R.A., Doyle, S., Asensio, M.A., Núñez, F., 2016. Increased chitin biosynthesis contributes to the resistance of Penicillium polonicum against the antifungal protein PgAFP. Appl. Microbiol. Biotechnol. 100, 371-383. http:// dx.doi.org/10.1007/s00253-015-7020-4.

Dolan, S.K., Owens, R.A., O'Keeffe, G., Hammel, S., Fitzpatrick, D.A., Jones, G.W., Doyle, S., 2014. Regulation of nonribosomal peptide synthesis: bisthiomethylation attenuates gliotoxin biosynthesis in Aspergillus fumigatus. Chem. Biol. 21, 999-1012. http://dx.doi.org/10.1016/j.chembiol.2014.07.006.

Fortwendel, J.R., Juvvadi, P.R., Perfect, B.Z., Rogg, L.E., Perfect, J.R., Steinbach, W.J., 2010. Transcriptional regulation of chitin synthases by calcineurin controls paradoxical growth of Aspergillus fumigatus in response to caspofungin. Antimicrob. Agents Chemother. 54, 1555-1563. http://dx.doi.org/10.1128/ AAC.00854-09.

Galgóczy, L., Kovács, L., Karácsony, Z., Virágh, M., Hamari, Z., Vágvölgyi, C., 2013. Investigation of the antimicrobial effect of Neosartorya fischeri antifungal protein (NFAP) after heterologous expression in Aspergillus nidulans. Microbiology 159, 411-419. http://dx.doi.org/10.1099/mic.0.061119-0.

Gautam, P., Shankar, J., Madan, T., Sirdeshmukh, R., Sundaram, C.S., Gade, W.N., 
Basir, S.F., Sarma, P.U., 2008. Proteomic and transcriptomic analysis of Aspergillus fumigatus on exposure to amphotericin B. Antimicrob. Agents Chemother. 52, 4220-4227. http://dx.doi.org/10.1128/AAC.01431-07.

Gomaa, O.M., Selim, N.S., Linz, J.E., 2013. Biochemical and biophysical response to calcium chloride stress in Aspergillus niger and its role in malachite green degradation. Cell Biochem. Biophys. 65, 413-423. http://dx.doi.org/10.1007/ s12013-012-9444-0.

Görg, A., Drews, O., Lück, C., Weiland, F., Weiss, W., 2009. 2-DE with IPGs. Electrophoresis 30 (Suppl. 1), S122-S132. http://dx.doi.org/10.1002/ elps.200900051.

Görg, A., Weiss, W., Dunn, M.J., 2004. Current two-dimensional electrophoresis technology for proteomics. Proteomics 4, 3665-3685. http://dx.doi.org/ 10.1002/pmic.200401031.

Hagen, S., Marx, F., Ram, A.F., Meyer, V., 2007. The antifungal protein AFP from Aspergillus giganteus inhibits chitin synthesis in sensitive fungi. Appl. Environ. Microbiol. 73, 2128-2134. http://dx.doi.org/10.1128/AEM.02497-06.

Harris, S.D., Morrell, J.L., Hamer, J., 1994. Identification and characterization of Aspergillus nidulans mutants defective in cytokinesis. Genetics 532, 517-532.

Juvvadi, P.R., Kuroki, Y., Arioka, M., Nakajima, H., Kitamoto, K., 2003. Functional analysis of the calcineurin-encoding gene cnaA from Aspergillus oryzae: evidence for its putative role in stress adaptation. Arch. Microbiol. 179, 416-422. http://dx.doi.org/10.1007/s00203-003-0546-3.

Juvvadi, P.R., Muñoz, A., Lamoth, F., Soderblom, E.J., Moseley, M.A., Read, N.D. Steinbach, W.J., 2015. Calcium-mediated induction of paradoxical growth following caspofungin treatment is associated with calcineurin activation and phosphorylation in Aspergillus fumigatus. Antimicrob. Agents Chemother. 59, 4946-4955. http://dx.doi.org/10.1128/AAC.00263-15.

Kaiserer, L., Oberparleiter, C., Weiler-Görz, R., Burgstaller, W., Leiter, E., Marx, F., 2003. Characterization of the Penicillium chrysogenum antifungal protein PAF. Arch. Microbiol. 180, 204-210. http://dx doi.org/10.1007/s00203-003-0578-8.

Kang, H.-J., Kim, B.-C., Park, E.-H., Ahn, K., Lim, C.-J., 2005. The gene encoding gamma-glutamyl transpeptidase II in the fission yeast is regulated by oxidative and metabolic stress. J. Biochem. Mol. Biol. 38, 609-618. http://dx.doi.org/ 10.5483/BMBRep.2005.38.5.609.

Kokkonen, M., Jestoi, M., Rizzo, A., 2005. Determination of selected mycotoxins in mould cheeses with liquid chromatography coupled to tandem with mass spectrometry. Food Addit. Contam. 22, 449-456. http://dx.doi.org/10.1080/ 02652030500089861.

Kong, Q., Wang, L., Liu, Z., Kwon, N.-J., Kim, S.C., Yu, J.-H., 2013. Gß-like CpcB plays a crucial role for growth and development of Aspergillus nidulans and Aspergillus fumigatus. PloS One 8, e70355. http://dx.doi.org/10.1371/journal.pone.0070355.

Kovács, L., Virágh, M., Takó, M., Papp, T., Vágvölgyi, C., Galgóczy, L., 2011. Isolation and characterization of Neosartorya fischeri antifungal protein (NFAP). Peptides 32, 1724-1731. http://dx.doi.org/10.1016/j.peptides.2011.06.022.

Lessing, F., Kniemeyer, O., Wozniok, I., Loeffler, J., Kurzai, O., Haertl, A. Brakhage, A.A., 2007. The Aspergillus fumigatus transcriptional regulator AfYap1 represents the major regulator for defense against reactive oxygen intermediates but is dispensable for pathogenicity in an intranasal mouse infection model. Eukaryot. Cell 6, 2290-2302. http://dx.doi.org/10.1128/ EC.00267-07.

Lie, J.L., Marth, E.H., 1967. Formation of aflatoxin in cheddar cheese by Aspergillus flavus and Aspergillus parasiticus. J. Dairy Sci. 50, 1708-1710 doi:S00220302(67)87698-7 [pii]/ r10.3168/jds.S0022-0302(67)87698-7.

López-Díaz, T.M., Román-Blanco, C., García-Arias, M.T., García-Fernández, M.C., García-López, M.L., 1996. Mycotoxins in two Spanish cheese varieties. Int. J. Food Microbiol. 30, 391-395.

Lowry, O.H., Rosebrough, N.J., Farr, L., Randall, R.J., 1951. Protein measurement with the folin phenol reagent. J. Biol. Chem. 193, 265-275.

Luber, C.A., Cox, J., Lauterbach, H., Fancke, B., Selbach, M., Tschopp, J., Akira, S., Wiegand, M., Hochrein, H., O'Keeffe, M., Mann, M., 2010. Quantitative proteomics reveals subset-specific viral recognition in dendritic cells. Immunity 32, 279-289. http://dx.doi.org/10.1016/j.immuni.2010.01.013.

Martín-Urdiroz, M., Martínez-Rocha, A.L., Pietro, A. Di, Martínez-del-Pozo, Á., Roncero, M.I.G., 2009. Differential toxicity of antifungal protein AFP against mutants of Fusarium oxysporum. Int. Microbiol. 12, 115-121. http://dx.doi.org/ 10.2436/20.1501.01.88

Marx, F., 2004. Small, basic antifungal proteins secreted from filamentous ascomycetes: a comparative study regarding expression, structure, function and potential application. Appl. Microbiol. Biotechnol. 65, 133-142. http:// dx.doi.org/10.1007/s00253-004-1600-z.

Marx, F., Binder, U., Leiter, E., Pócsi, I., 2008. The Penicillium chrysogenum antifungal protein PAF, a promising tool for the development of new antifungal therapies and fungal cell biology studies. Cell. Mol. Life Sci. 65, 445-454. http:// dx.doi.org/10.1007/s00018-007-7364-8.

Marx, F., Haas, H., Reindl, M., Stöffler, G., Lottspeich, F., Redl, B., 1995. Cloning, structural organization and regulation of expression of the Penicillium chrys ogenum paf gene encoding an abundantly secreted protein with antifungal activity. Gene 167, 167-171.

Nakaya, K., Omata, K., Okahashi, I., Nakamura, Y., Kolkenbrock, H., Ulbrich, N., 1990 Amino acid sequence and disulfide bridges of an antifungal protein isolated from Aspergillus giganteus. Eur. J. Biochem. 38, 32-38.

Nelson, G., Kozlova-Zwinderman, O., Collis, A.J., Knight, M.R., Fincham, J.R.S Stanger, C.P., Renwick, A., Hessing, J.G.M., Punt, P.J., Van Den Hondel, C.A.M.J.J., Read, N.D., 2004. Calcium measurements in living filamentous fungi expressing codon-optimized aequorin. Mol. Microbiol. 52, 1437-1450. http://dx.doi.org $10.1111 / j .1365-2958.2004 .04066 . x$.

O'Keeffe, G., Hammel, S., Owens, R.A., Keane, T.M., Fitzpatrick, D.A., Jones, G.W. Doyle, S., 2014. RNA-seq reveals the pan-transcriptomic impact of attenuating the gliotoxin self-protection mechanism in Aspergillus fumigatus. BMC Genomics 25, 1-26. http://dx.doi.org/10.1186/1471-2164-15-894.

Owens, R.A., Hammel, S., Sheridan, K.J., Jones, G.W., Doyle, S., 2014. A proteomic approach to investigating gene cluster expression and secondary metabolite functionality in Aspergillus fumigatus. PloS One 9, e106942. http://dx.doi.org/ 10.1371/journal.pone.0106942.g001.

Owens, R.A., O'Keeffe, G., Smith, E.B., Dolan, S.K., Hammel, S., Sheridan, K.J. Fitzpatrick, D.A., Keane, T.M., Jones, G.W., Doyle, S., 2015. Interplay between gliotoxin resistance, secretion, and the methyl/methionine cycle in Aspergillus fumigatus. Eukaryot. Cell 14, 941-957. http://dx.doi.org/10.1128/EC.00055-15.

Park, H.-J., Lim, H.-W., Kim, K., Kim, I.-H., Park, E.-H., Lim, C.-J., 2004. Characterization and regulation of the $\gamma$-glutamyl transpeptidase gene from the fission yeast Schizosaccharomyces pombe. Can. J. Microbiol. 50, 61-67. http://dx.doi.org/ 10.1139/w03-106.

Park, H.-J., Moon, J.-S., Kim, H.-G., Kim, I.-H., Kim, K., Park, E.-H., Lim, C.-J., 2005 Characterization of a second gene encoding $\gamma$-glutamyl transpeptidase from Schizosaccharomyces pombe. Can. J. Microbiol. 51, 269-275. http://dx.doi.org/ 10.1139/w04-137.

Priebe, S., Linde, J., Albrecht, D., Guthke, R., Brakhage, A.A., 2011. FungiFun: a webbased application for functional categorization of fungal genes and proteins. Fungal Genet. Biol. 48, 353-358. http://dx.doi.org/10.1016/j.fgb.2010.11.001.

Rabilloud, T., Vaezzadeh, A.R., Potier, N., 2009. Power and limitations of electrophoretic. Mass Spectrom. Rev. 28, 816-843. http://dx.doi.org/10.1002/mas.

Rodríguez-Martín, A., Acosta, R., Liddell, S., Núñez, F., Benito, M.J., Asensio, M.A. 2010. Characterization of the novel antifungal protein PgAFP and the encoding gene of Penicillium chrysogenum. Peptides 31, 541-547. http://dx.doi.org/ 10.1016/j.peptides.2009.11.002.

Rüegg. M., Blanc, B., 1981. Influence of water activity on the manufacture and aging of cheese. In: Rockland, L.B., Stewart, G.F. (Eds.), Water Activity: Influences on Food Quality. Academic Press, New York, pp. 791-811.

Shevchenko, A., Tomas, H., Havlis, J., Olsen, J.V., Mann, M., 2006. In-gel digestion for mass spectrometric characterization of proteins and proteomes. Nat. Protoc. 1 , 2856-2860. http://dx.doi.org/10.1038/nprot.2006.468.

Soriani, F.M., Malavazi, I., Da Silva Ferreira, M.E., Savoldi, M., Von Zeska Kress, M.R. De Souza Goldman, M.H., Loss, O., Bignell, E., Goldman, G.H., 2008. Functional characterization of the Aspergillus fumigatus CRZ1 homologue, CrzA. Mol. Microbiol. 67, 1274-1291. http://dx.doi.org/10.1111/j.1365-2958.2008.06122.x.

Springael, J.-Y., Penninckx, M.J., 2003. Nitrogen-source regulation of yeast gammaglutamyl transpeptidase synthesis involves the regulatory network including the GATA zinc-finger factors Gln3, Nil1/Gat1 and Gzf3. Biochem. J. 371, 589-595. http://dx.doi.org/10.1042/BJ20021893.

Theis, T., Wedde, M., Meyer, V., Stahl, U., 2003. The antifungal protein from Aspergillus giganteus causes membrane permeabilization. Antimicrob. Agents Chemother. 47, 588-593. http://dx.doi.org/10.1128/AAC.47.2.588.

Thevissen, K., Ghazi, A., De Samblanx, G.W., Brownlee, C., Osborn, R.W. Broekaert, W.F., 1996. Fungal membrane responses induced by plant defensins and thionins. J. Biol. Chem. 271, 15018-15025.

Thevissen, K., Terras, F.R., Broekaert, W.F., 1999. Permeabilization of fungal membranes by plant defensins inhibits fungal growth. Appl. Environ. Microbiol. 65, 5451-5458.

Thewes, S., 2014. Calcineurin-Crz1 signaling in lower eukaryotes. Eukaryot. Cell 13, 694-705. http://dx.doi.org/10.1128/EC.00038-14.

Zhu, W., Smith, J.W., Huang, C.-M., 2010. Mass spectrometry-based label-free quantitative proteomics. J. Biomed. Biotechnol. 2010, 1-6. http://dx.doi.org/ $10.1155 / 2010 / 840518$ 